\title{
Calcicole plant diversity in
}

Switzerland may reflect a variety of

\section{habitat templets}

\section{Journal Article}

\section{Author(s):}

Wohlgemuth, Thomas; Gigon, Andreas

Publication date:

2003-12

Permanent link:

https://doi.org/10.3929/ethz-b-000052796

\section{Rights / license:}

In Copyright - Non-Commercial Use Permitted

Originally published in:

Folia geobotanica 38(4), https://doi.org/10.1007/BF02803251 


\title{
Calcicole Plant Diversity in SWitzerland May REFLECT A VARIETY OF HABITAT TEMPLETS
}

\author{
Thomas Wohlgemuth ${ }^{1)}$ \& Andreas Gigon ${ }^{2)}$ \\ 1) Swiss Federal Institute for Forest, Snow and Landscape Research WSL, Zürcherstrasse 111, CH-8903 \\ Birmensdorf, Switzerland; fax+4117392215,e-mail thomas.wohlgemuth@wsl.ch \\ 2) Geobotanical Institute ETH, Swiss Federal Institute of Technology, Gladbachstrasse 114, CH-8044 Zürich, \\ Switzerland
}

\begin{abstract}
The study of the disparity concerning the sizes of calcicole and calcifuge floras in Central Europe is a surprisingly young scientific branch. Accordingly, explanations of the patterns have not yet been consolidated. In this paper, we comment on the solution of the "calcareous riddle" proposed by Jörg EWALD (Folia Geobot. 38: $357-366,2003)$. On the basis of flora and vegetation data bases, we tested the phenomenon of calcicole richness by analyzing the forest vegetation and the flora of Switzerland and found corresponding patterns. A clear overbalance of calcareous forest habitats contrasts with an overbalance of acidic topsoils, as derived from a large representative sample in Swiss forests. Calcicole/calcifuge ratios reveal an overbalance of calcicoles in most mapping units of the distribution atlas of vascular plants in Switzerland. Central crystalline parts of the Alps, however, show a clear overbalance of calcifuges. Patterns from the different community and regional scales are explained by (micro-)habitat diversity. With respect to the "calcareous riddle", we question several assumptions, e.g. the time considered before the Pleistocene bottleneck, the area considered for speciation/extinction, and the role of habitat diversity rather than two substrate classes.
\end{abstract}

Keywords: Calcicoles and calcifuges, Floras, Habitat templet, Indicator plant species, Plant species richness, Soil pH, Switzerland

\section{INTRODUCTION}

The question why some substrates host different plant species than others is old, and generations of plant ecologists have put emphasis on it (UNGER 1836, MEVIUS 1927, ELLENBERG 1958, KINZEL 1983). It is now generally accepted that the main answer lies in chemical processes and factors rather than in physical ones such as soil temperature or moisture (KINZEL 1983, GIGON 1987). In contrast, the derived question of whether plant species richness differs depending on calcareous or acidic substrate has thus far been of minor scientific interest in Europe. GRIME (1979) vulgarized the phenomenon of the overbalance of calcicole species on the British Islands. He explained the "reservoir effect" (PÄRTEL 2002) by an evolution of calcicoly in semi-arid environments at lower latitudes where a high base-status in the soils was maintained by low precipitation/evapotranspiration ratios.

EWALD (2003), in his stimulating proposal, demonstrates the same disparity of calcicoles/calcifuges for forests in Central Europe (Germany) and proposes the "inherited species-area relationship"-hypothesis to solve the "calcareous riddle". According to his hypothesis, the overbalance of calcicoles in Central Europe is a result of ecological drift 
imposed by the historical substrate bottleneck that resulted from glaciation effects and that caused extinction of more calcifuge than calcicole species.

Plant species richness in Central Europe often peaks on calcareous habitats. The local feature seems to be consistent with the more general global phenomenon that numbers of species "suited for high $\mathrm{pH}$ " in a region exceed the numbers of species "suited for low $\mathrm{pH}$ " (PÄRTEL 2002). In Switzerland, where different rock types along the Alpine Arc or on the Jura Mountains can build extensive areas of special substrates, the highest number of plant species is neither found on explicitly calcareous substrate nor on explicitly silicate or acidic substrate. At the landscape or regional scale, species richness is largest on mixed substrates such as Flysch or Bündner schist (e.g. WOHLGEMUTH 2002a,b). At the community or plot scale in forests, neutral or weakly basic substrates are richer in plant species than acidic or extremely calcareous substrates (KELLER et al. 1998).

In this paper, we comment on the propositions of EWALD (2003) to solve the "calcareous riddle". We discuss the definitions related to calcicoly and calcifugy, and focus on substrate dependency of species richness of communities (alpha-diversity) and of regions (gamma-diversity) in Switzerland. We show that physiological constraints hold only for a small proportion of plants, and we propose the historical presence of various habitat templets to explain the current calcicole/calcifuge portions of alpha- and gamma-diversity in Switzerland.

\section{Indicator plant species for substrate}

In the following, no attempt is made to summarize the exhaustive literature (e.g. ELLENBERG 1958, KINZEL 1983) on the concepts and definitions concerned with the observation that floristic differences exist between the calcareous and non-calcareous substrates. The most neutral "descriptive terms" (KINZEL 1983) for this phenomenon are, in our opinion: calcicoles, i.e., species (predominantly) occurring on calcareous habitats, and calcifuges, i.e., not occurring on these habitats. The many terms with "-philous" and "-phobic" imply that the species "like" or "dislike" the particular habitat, mainly for physiological reasons (KINZEL 1983). However, there are many species where this is not the case, as shown below.

To our knowledge, the first lists of substrate indicator species referred to the mountain region of Kitzbühel, Austria (UNGER 1836). VON MOHL (1845) defined substrate preferences for 752 species of the Alps. In that early paper, species were categorized into five classes that more or less correspond to the classification of Swiss plants elaborated by LANDOLT (1977) with its $\mathrm{R}_{\mathrm{L}}$-values ranging from 1 to 5 for very acidic to neutral or slightly basic soils (comparison with ELLENBERG et al. 1991 in Table 1). According to von Mohl's list, 20\% of the 752 species he studied are strictly calcicoles and $14 \%$ are strictly calcifuges. Revised information based on observations and experiments on the species' response to substrate are reflected today by Landolt's list, in which merely $3.9 \%$ of the 3364 Swiss plant species are strongly restricted to calcareous substrate $\left(\mathrm{R}_{\mathrm{L}} 5\right)$ and $1.3 \%$ to acidic substrate (including peaty substrate; $\mathrm{R}_{\mathrm{L}} 1$ ), respectively. In other words, only about $5 \%$ of the Swiss plants are considered true substrate specialists. Most of the other species can be merged into a large group of species with broader physiological tolerance and in which interspecific competition 
Table 1. $R_{L}$-values of LANDOLT (1977) for the Swiss flora (numbers in brackets), compared with $R_{E}$-values of ELLENBERG et al. (1991).

\begin{tabular}{|c|c|c|}
\hline Landolt $R_{L}$ & Ellenberg $R_{E}$ & Description \\
\hline \multirow[t]{2}{*}{$1(44)$} & 1 & $\begin{array}{l}\text { Strict calcifugy; indicator of extreme acidity, never found on } \\
\text { weakly acidic or basic soils }\end{array}$ \\
\hline & 2 & Between $R_{E} 1$ and $R_{E} 3$ \\
\hline \multirow[t]{2}{*}{$2(571)$} & 3 & $\begin{array}{l}\text { Acidity indicator, mainly on acidic soils, but exceptionally also on } \\
\text { nearly neutral ones }\end{array}$ \\
\hline & 4 & Between $R_{E} 3$ and $R_{E} 5$ \\
\hline \multirow[t]{2}{*}{$3(1491)$} & 5 & $\begin{array}{l}\text { Indicator of moderately acidic soils, only occasionally found on } \\
\text { very acidic or on neutral to basic soils }\end{array}$ \\
\hline & 6 & Between $R_{E} 5$ and $R_{E} 7$ \\
\hline \multirow[t]{2}{*}{$4(1107)$} & 7 & $\begin{array}{l}\text { Indicator of weakly acidic to weakly basic conditions; never } \\
\text { found on very acidic soils }\end{array}$ \\
\hline & 8 & Between $R_{E} 7$ and $R_{E} 9$ \\
\hline $5(131)$ & 9 & $\begin{array}{l}\text { Strict calcicoly; indicator of basic reaction, always found on } \\
\text { calcareous or other high-pH soils }\end{array}$ \\
\hline
\end{tabular}

defines the ecological niche to an increasing degree (see below). In terms of Ellenberg indicator value system (used by EWALD 2003), the substrate specialists correspond to the $\mathrm{R}_{\mathrm{E}} 1$

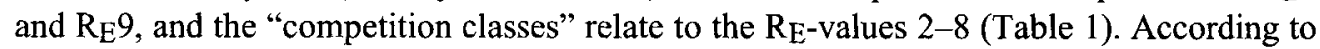
our considerations, the separation of plant species into only two rough substrate classes (EWALD 2003) does not reflect the variety of different physiological and ecological amplitudes for the species' occurrence in nature. By applying such a rough dichotomy of species with respect to substrate, the real variety of reactions may be generalized too much.

Factors such as water, light or nutrient availability are considered primary limiting factors (WALTER 1960). Plants are either limited directly by the amount or the regime of these factors, or indirectly by interspecific competition. The latter ecological aspect was not taken into account in EWALD (2003). GIGON (1987) and others have shown that many calcicole species can grow on acidic habitats (of $\mathrm{pH}\left(\mathrm{H}_{2} \mathrm{O}\right)>5$ ) if competition by calcifuge species is excluded. For example, 31 calcicoles out of the 55 species characteristic for an alpine grassland (partly corresponding to the Seslerio-Caricetum sempervirentis) on calcareous habitat, can grow on an acidic alpine soil of $\mathrm{pH}\left(\mathrm{H}_{2} \mathrm{O}\right)$ 5-6 in competition-free plots (GIGON 1987). Similar situations exist even in the field where calcicole species can be found on acidic rocky soils of alpine, south-exposed slopes (GIGON 1971). As ELLENBERG (1996) outlined with his "ecogram approach", the physiological growth limits of a species may be considerably larger than its ecological amplitude that we observe today in actual communities. The ecogram approach corresponds with the concept of the fundamental and the realized niche (HUTCHINSON 1965). 


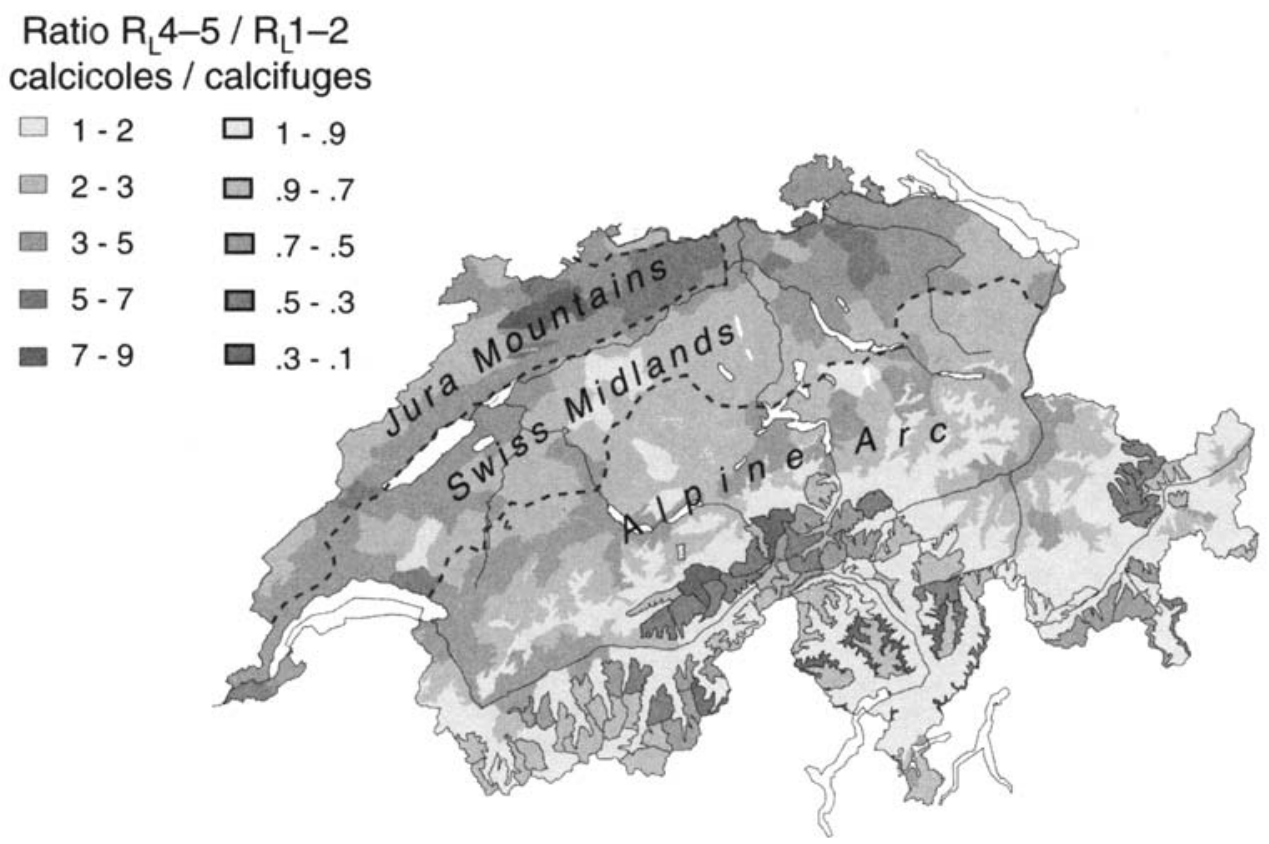

Fig. 1. Disparity of calcicoles or calcifuges in Switzerland at the regional scale, displayed by the ratio of calcicole ( $\left.\mathrm{R}_{\mathrm{L}} 4-5\right)$ / calcifuge $\left(\mathrm{R}_{\mathrm{L}} 1-2\right)$, according to indicator values of LANDOLT (1977) and the "Swiss Web Flora" (WELTEN \& SUTTER 1982, WOHLGEMUTH 1999). In framed mapping units, the ratio is $\leq 1$, i.e., the number of calcifuges is larger than the numbers of calcicoles.

\section{Proportion of calcicoles at regional scales}

The general assumption that floras of Central Europe have greater numbers of calcicoles than calcifuges (PÄRTEL 2002) is supported by the numbers of Landolt's reaction indicators for the Swiss flora (LANDOLT 1977; Table 1). However, when focusing on smaller areas, e.g. at regional scales ranging between 1 to $100 \mathrm{~km}^{2}$, more subtle substrate-dependent patterns emerge. Fig. 1 shows the ratio of calcicoles/calcifuges, i.e., $R_{L} 4-5 / R_{L} 1-2$, for 565 contiguous mapping units of the inventory of the Swiss flora (28 lake units were excluded). Accordingly, calcicoles prevail along the calcareous Jura Mountains, in the Swiss Midlands (Central Plateau) and along the calcareous northern front range of the Alps. In the crystalline central ranges of the Alps, however, calcifuges are more numerous than calcicoles. Most of the mapping units with an overbalance of calcifuges are located above the timberline (Fig. 2). In the inventory of the Swiss vascular plants (WELTEN \& SUTTER 1982), 350 lowland units below the timberline were distinguished from 215 mountain units above the timberline. In contrast to inventories of other European countries, the mapping units in Switzerland were topographically defined. The scatter plot in Fig. 2 indicates the largest values for species richness above the timberline at calcicole/calcifuge ratios of 1 to 2 . In contrast, total species richness in mapping units below the timberline peak at higher ratio values, indicating the marked overbalance of calcicoly below the timberline. Because the geology of Switzerland 


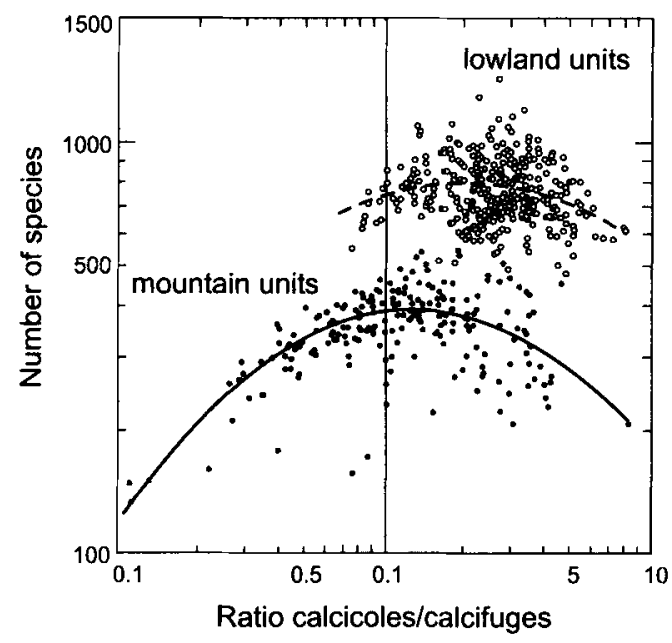

Fig. 2. Ratio of calcicoles or calcifuges vs. regional species richness in mapping units of the Swiss floristic inventory, according to indicator values of LANDOLT (1977) and the "Swiss Web Flora" (WELTEN \& SUTTER 1982, WOHLGEMUTH 1999). Statistics of the polynomial regression, for lowland units: $\log 10$ (\# species) $=-0.3258[\log 10 \text { (ratio) }]^{2}$ $+0.2108 \log 10$ (ratio) +2.8652 with $r^{2}=0.0546, P<0.01$; for mountain units: $\log 10$ (\# species) $=-0.4147[\log 10(\text { ratio })]^{2}+0.1056 \log 10$ (ratio) +2.5802 with $r^{2}=0.4205, P<0.001$. base-rich glacial till or loess several times during the Pleistocene, resulting in a low apparency of acid soils in this time period. The proposed disparity of acidic habitats may explain the substrate bottleneck (EWALD 2003).

\section{Proportion of calcicoles at community scales}

Species lists of "calcareous" habitats are often longer than lists of equal sized acidic habitats. Often, the greater richness of calcareous habitats results from the co-occurrence of calcicoles and calcifuges due to microhabitat structure (KINZEL 1983). Carbonate rock gets easily dissolved. Increased and continuous precipitation along mountain ranges intensifies this process and eventually results in acidic microhabitats ranging from $\mathrm{cm}^{2}$ to many $\mathrm{m}^{2}$ even at places where (a) only carbonate rocks compose the bedrock of soil formation and (b) soil development started after the last glacier retreated, i.e., at the beginning of the Holocene, about $10 \mathrm{k}$ yr ago (HANTKE 1978-1983). For example: Luzula silvatica and Vaccinium myrtillus (Landolt indicator values $\mathrm{R}_{\mathrm{L}} 2$ and $\mathrm{R}_{\mathrm{L}} 1$ ) occur in Silver Fir-Beech-forests (Abieti-Fagetum luzuletosum) on calcareous substrates along the Swiss Pre-Alps (KELLER et al.1998). Similarly, Nardus stricta $\left(\mathrm{R}_{\mathrm{L}} 2\right)$, Geum montanum $\left(\mathrm{R}_{\mathrm{L}} 2\right)$ and Vaccinium myrtillus $\left(\mathrm{R}_{\mathrm{L}} 1\right)$ can be found in a purely dolomitic mountain range near Davos (eastern Switzerland, pers. observation). Along the calcareous Jura Mountains, forest communities on acidic moraine deposits occur (RICHARD 1961). There are many more examples demonstrating that 


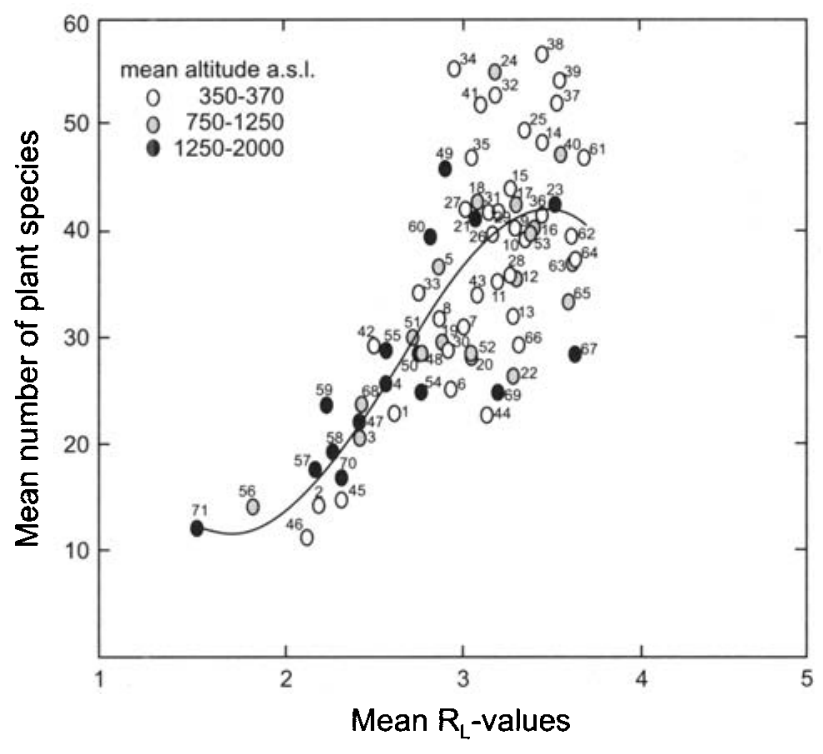

Fig. 3. Mean species richness in all 71 Swiss forest communities, based on 2538 relevés in KELLER et al. (1998), displayed along mean Landolt indicator values (LANDOLT 1977). $\mathrm{R}_{\mathrm{L}} 1$ means very acidic, $R_{L} 5$ neutral or basic soils (see Table 1 ). Labels refer to the community numbers of the Swiss classification system. Statistics of the polynomial regression: species number $=-0.1553 R_{L}{ }^{4}-9.6866$ $\mathrm{R}_{\mathrm{L}}{ }^{3}+81.68 \mathrm{R}_{\mathrm{L}}{ }^{2}-191.13 \mathrm{R}_{\mathrm{L}}+148.88, r^{2}=0.579, P<0.001$. The $r^{2}$ for the linear regression was $0.532, P<0.001$.

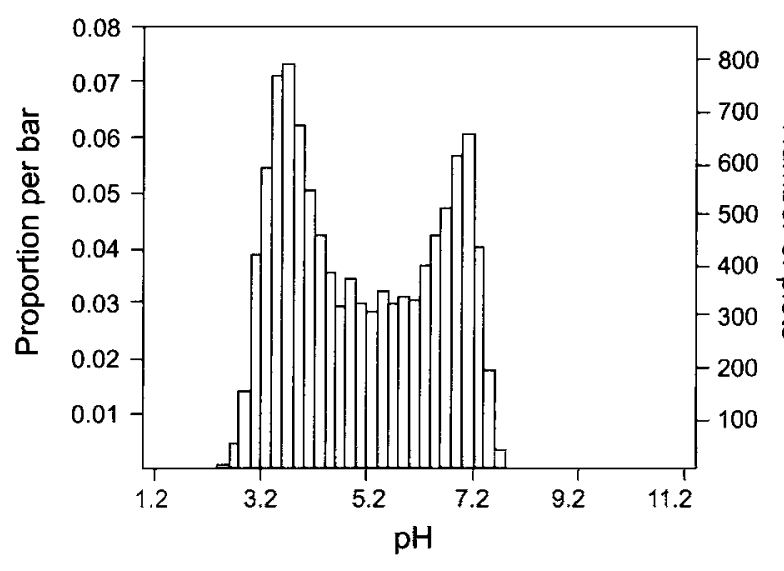

Fig. 4. Histogram of $\mathrm{pH}$ of soil samples $\left(0.01 \mathrm{M} \mathrm{CaCl}_{2}\right)$ taken from top $20 \mathrm{~cm}$ in 10,864 forest plots on a systematic grid sample representing all forests of Switzerland (EAFV 1988). great species richness on calcareous habitats results from the presence of both calcicoles as well as calcifuges on acidic microhabitats.

According to the general distinction between igneous, sedimentary and metamorphic rocks, the diversity of bedrock substrates containing carbonate may be greater than substrate diversity without carbonate, at least for the Alpine Arc. Igneous rocks such as granite have appeared in mass during the uplifting of the Alps and today build the central massif in the Swiss Alps. At the front ranges, calcareous sedimentary rocks such as limestone dominate. Carbonate-containing sediments such as schist or flysch cover large areas of the Alps. Only in the Southern Alps, metamorphic gneiss, in general poor in carbonate, build extensive areas. As a result of a greater texture diversity and greater substrate diversity of sedimentary (mostly calcareous) rocks, the habitat diversity on these substrates may be expected to be greater. In accordance to such an expectation, the list of habitat types of Switzerland (DELARZE et al. 1999) indicates 56 habitats on basic substrates or soils, whereas only 40 are listed being particularly on acidic substrates or soils (including organic soils). Similar to the general habitat disparity outlined, the majority of 71 forest communities 
distinguished in Switzerland (KELLER et al. 1998) also grows on neutral or calcareous substrate indicated by averaged $R_{L}$-value for 2538 relevés (Fig. 3). In addition, there is a significant trend towards greater species richness with increasing average indicator value for soil reaction. In contrast to the overbalance of calcareous habitats, the $\mathrm{pH}$ of topsoils in Swiss forests reveal a slight overbalance towards acidic substrates (Fig. 4). Results were derived from a representative sample in the frame of the Swiss National forest inventory (EAFV 1988). These results correspond with the substrate situation of forest habitats in Germany presented in EWALD (2003). The overbalance of acidic substrates (at least concerning the topsoils) is not reflected by an overbalance of different acidic forest habitats. Thus, species diversity may be adequately explained by habitat diversity rather than acidic substrate. With respect to the actual substrate situation, there are fewer different habitats on acidic substrates than on neutral or calcareous substrates.

\section{Open questions: substrates and climates before and during Pleistocene}

According to the "inherited species-area relationship"-hypothesis of EWALD (2003), the disparity between the numbers of calcicoles and calcifuges reflects a historical overbalance of calcareous substrate during the Pleistocene caused by substrate rejuvenation and range contraction due to several glaciations. The hypothesis is - at first sight - plausible with respect to a large region of Central Europe. Increased extinction rates caused by repeated habitat changes due to glaciation serve as a valuable starting point to unravel the riddle, but there remain several questions to ask.

(1) What role does climate play in the calcareous riddle? Bedrock or substrate is one factor related to niche differentiation and eventually speciation, another one is climate. The climate from Paleocene to Pliocene was constantly subtropical or tropical in western and central Europe (e.g. LARCHER \& BAUER 1981, BEHRENSMEYER et al. 1992, LANG 1994), with a remarkable cooling during Miocene and Pliocene that resulted in the replacement of the evergreen subtropical flora by a deciduous temperate and frost-resistant woodland flora (LARCHER \& BAUER 1981). Long before the beginning of the Pleistocene (2.4 M yr), the diverse subtropical flora in Europe became extinct (LANG 1994). Since the Miocene, no massive changes at the generic level have occurred (TRAVERSE 1988). At that time, new centres of speciation were presumably located in the Mediterranean (LANG 1994), where species adapted to a dry-summer climate, and in the newly formed Alps (adaptation to harsh climates and different substrates; see also AGAKHANJANZ \& BRECKLE 1995). In addition, West-Siberian taxa invaded European habitats by the new land bridge between Europe and West Asia (LANG 1994). Species composition before Pleistocene was clearly different from today's flora. With respect to PÄRTEL's (2002) results, low pH and high species richness is a typical feature of tropical or subtropical floras, i.e., floras that today are located at low latitudes.

(2) To which evolutionary time does the calcareous riddle refer? EWALD (2003) termed the time before the Pleistocenic bottleneck "Tertiary". Although the time before Pleistocene is properly addressed "Tertiary", we consider the climatic changes during Miocene and Pliocene that resulted in a vegetation shift from suptropical to temperate vegetation not properly accounted for (BEHRENSMEYER et al. 1992, LANG 1994). 
(3) When and where did the residential calcicoles and calcifuges of Central Europe evolve? Many plant species with conspicuous disjunct distribution patterns are termed Tertiary relicts, i.e., plant species that have survived the Ice Age in refugial places or on nunataks (HANTKE 1984, SEITTER \& HANTKE 1988, HANTKE et al. 2000, STEHLIK 2000). The existence of Tertiary relicts not only demonstrates the importance of the temporal and spatial constancy of sites, i.e., the so-called habitat templets (SOUTHWOOD 1977). It also confirms the concepts of the phylogenetic conservatism (PEAT \& FITTER 1994) and of the related niche conservatism (PRINZING et al. 2001) that explains traits of extant plant species by the opportunities of their ancestors during their diversification. A majority of Swiss plant species have not evolved within their current ranges. However, it is likely that most of the 350 endemics along the Alpine Arc (PAWLOWSKI 1970) are extant species of old resident pools. According to BEHRENSMEYER et al. (1992), all genera of extant plant species are represented in fossil pollen of the Pliocene, or $10 \mathrm{M}$ yr BP (TRAVERSE 1988). The question arises to which extent the residential plant species of Central Europe evolved during the Pliocene and the Pleistocene. In addition, which role did the existence of mountain plant species play for the evolution of lowland species (e.g. LANDOLT 1970) and vice versa?

(4) To which extent is habitat diversity reflected by area size of substrate habitats? EWALD (2003) postulated the acidic habitat area to be larger in the Tertiary than in the Pleistocene. If this assumption holds, then the next question arises whether the very general class of "acidic substrate" is equal, larger or smaller with respect to other site conditions, such as moisture, warmth and light, than the general class of "calcareous substrates" (e.g. habitat numbers in Switzerland; see above). Depending on the historical and regional geology of concern, differences in habitat diversity may be considerable. However, the assumption that acidic habitats covered larger areas before and smaller areas during the Ice Age in Central Europe may be debated. Whereas the largest glaciation Riss/Saale covered half of Central Europe, the later Würm/Weichsel glaciation was considerably smaller (ANONYMOUS 1988). With respect to acidic habitat templets, these habitats may have existed at any time during the Ice Age and in still very large areas despite extensive glaciations. Examples of acidic habitats on totally leached Riss moraines in the Swiss Midlands are given by FREHNER (1963).

In conclusion, EWALD's (2003) hypothesis to explain the "calcareous riddle" in the forest flora of Central Europe is stimulating with respect to its general and plausible approach. Many features found in the current vegetation and flora of Switzerland confirm the phenomenon of the calcicole richness. As shown, the hypothesis opens many new questions. The subject of the calcicole richness or the "calcicole riddle" is very complex, however. In addition to modern tools such as the calibration of taxa lineages (e.g. BREMER 2000, WIKSTRÖM et al. 2001), a large body of literature of different disciplines such as geology, palynology, paleoecology, phylogeography, plant ecology and community ecology needs to be synthesized and reflected with respect to modern concepts such as the habitat templet model (SOUTHWOOD 1977), the species pool concept (TAYLOR et al. 1990, AARSSEN \& SCHAMP 2002) and the phylogenetic conservatism concept (PEAT \& FITTER 1994, PRINZING et al. 2001).

Acknowledgements: We thank Walter Keller, Martin Schütz (Birmensdorf) and Frank Klötzli (Zürich) for fruitful discussions, and Felix Gugerli and two anonymous referees for helpful comments on the manuscript. 


\section{REFERENCES}

AARSSEN L.W. \& SCHAMP B.S. (2002): Predicting distributions of species richness and species size in regional floras: applying the species pool hypothesis to the habitat templet model. Perspect. Pl. Ecol. Evol. Syst. 5: 3-12.

AGAKHANJANZ O. \& BRECKLE S.-W. (1995): Origin and evolution of the mountain flora in Middle Asia and neighbouring mountain regions. In: CHAPIN III F.S. \& KÖRNER C. (eds.), Arctic and alpine biodiversity: patterns, causes and ecosystem consequences, Ecological Studies 113, Springer, Berlin, pp. 63-80.

ANONYMOUS (1988): Brockhaus Enzyklopädie: Ds - Ew und erster Nachtrag (Vol. 6). Ed. 19. Mannheim.

Behrensmeyer A.K., DAMUTH J., Dimichele W., PotTs R., SUES H.D. \& Wing S. (1992): Terrestrial ecosystems through time. University of Chicago Press, Chicago.

BREMER K. (2000): Early Cretaceous lineages of monocot flowering plants. Proc. Natl. Acad. Sci. USA 97: $4707-4711$.

Delarze R., GonseTH Y. \& GALland P. (1999): Lebensräume der Schweiz: Ökologie, Gefährdung, Kennarten. Ott, Thun.

EAFV (1988): Schweizerisches Landesforstinventar: Ergebnisse der Erstaufnahme 1982-1986. Ber. Eidgenöss. Anst. Forstl. Versuchswesen 305: 1-375.

ELlENBERG H. (1958): Bodenreaktion (einschliesslich Kalkfrage). In: RUHLAND W. (ed.), Handbuch der Pflanzenphysiologie: Vol. 4. Die mineralische Ernährung der Pflanze, Springer, Berlin, pp. 638-708.

ELLENBERG H. (1996): Vegetation Mitteleuropas mit den Alpen. Ed. 5. Ulmer, Stuttgart.

EllenberG H., Weber H.E., Düll R., WirTh V., Werner W. \& PAUlissen D. (1991): Zeigerwerte von Pflanzen in Mitteleuropa. Scripta Geobot. 18: 1-248.

EWALD J. (2003): The calcareous riddle: why are there so many calciphilous species in the Central European flora? Folia Geobot. 38: 357-366 (this issue).

FREHNER H.K. (1963): Waldgesellschaften im westlichen Aargauer Mittelland. Beitr. Geobot. Landesaufn. Schweiz 44: 1-99.

GIGON A. (1971): Vergleich alpiner Rasen auf Silikat- und Karbonatboden. Konkurrenz- und Stickstofformenversuche sowie standortskundliche Untersuchungen im Nardetum und im Seslerietum bei Davos. Veröff. Geobot. Inst. ETH, Stiftung Rübel, Zürich 48: 1-159.

GIGON A. (1987): A hierarchic approach in causal ecosystem analysis: the calcifuge-calcicole problem in Alpine grasslands. Ecol. Stud. 61: 228-244.

GRIME J.P. (1979): Plant strategies and vegetation processes. Wiley, Chichester.

GRUBB P.J. (1987): Global trends in species-richness in terrestrial vegetation: a view from the northern hemisphere. In: GEE J.H.R. \& GILLER P.S. (eds.), Organization of communities, Blackwell, Oxford, pp. $99-118$.

HANTKE R. (1978-1983): Eiszeitalter. Die jüngste Erdgeschichte der Schweiz und ihrer Nachbargebiete. Ott, Thun.

HANTKE R. (1984): Vermochten an nie vereisten Lagen des Randen (Kanton Schaffhausen und badische Grenzgebiete) jüngsttertiäre Florenrelikte die Eiszeiten zu überdauem? Eclogae Geol. Helv. 77: 707-719.

HANTKE R., WagneR G., Schatz W. \& SEITTER H. (2000): Präglaziale Florenrelikte im Rigi- und Brienzer-Rothorn-Gebiet. Vierteljahrsschr. Naturf. Ges. Zürich 145: 65-85.

HUSTON M. A. (1979): A general hypothesis of species diversity. Amer. Naturalist 113: 81 101.

HUTCHINSON G.E. (1965): The ecological theater and the evolutionnary play. Yale University Press, New Haven.

KELLER W., WOHLGEMUTH T., KUHN N., SCHÜTZ M. \& WILDI O. (1998): Waldgesellschaften der Schweiz auf floristischer Grundlage. Statistisch überarbeitete Fassung der "Waldgesellschaften und Waldstandorte der Schweiz" von Heinz Ellenberg und Frank Klötzli 1972. Mitt. Eidg. Forsch. Anst. Wald Schnee Landschaft 73: 91-355.

KINZEL H. (1983): Influence of limestone, silicates and soil pH on vegetation. In: LANGE O.L., NOBEL P.S., OSMOND C.B. \& ZIEGLER H. (eds.), Encyclopedia of plant physiology, New Series, Vol. 12c, Physiological plant ecology III: Responses to the chemical and biological environment, Springer, Berlin, Heidelberg, New York, pp. 201-244. 
LANDOLT E. (1970): Mitteleuropäische Wiesenpflanzen als hybridogene Abkömmlinge von mittel- und südeuropäischen Gebirgssippen und submediterranen Sippen. Feddes Repert. 81: 61-66.

LANDOLT E. (1977): Ökologische Zeigerwerte zur Schweizer Flora. Veröff. Geobot. Inst. ETH, Stiftung Rübel, Zürich 64: 1-208.

LANG G. (1994): Quartäre Vegetationsgeschichte Europas: Methoden und Ergebnisse. Gustav Fischer, Jena.

LARCHER W. \& BAUER H. (1981): Ecological significance of resistance to low temperature. In: LANGE O.L., NOBEL P.S., OSMOND C.B. \& ZIEGLER H. (eds.), Encyclopedia of plant physiology, New Series Vol. $12 a$, Physiological plant ecology I: Responses to the physical environment, Springer, Berlin, Heidelberg, New York, 403-437.

Mevius W. (1927): Reaktion des Bodens und Pflanzenwachstum. Datterer, Freising.

PÄRTEL M. (2002): Local plant diversity patterns and evolutionary history at the regional scale. Ecology 83 : $2361-2366$.

PAWLOWSKI B. (1970): Remarques sur l'endémisme dans la flore des Alpes et des Carpates. Vegetatio 21: $181-243$.

PEAT H.J. \& FITTER A.H. (1994): Comparative analyses of ecological characteristics of British angiosperms. Biol. Rev. 69: 95-115.

PRINZING A., DURKA W., KLOTZS. \& BRANDL R. (2001): The niche of higher plants: evidence for phylogenetic conservatism. Proc. Roy. Soc. London, Ser. B, Biol. Sci. 268: 2383-2389.

RICHARD J.L. (1961): Les forêts acidophiles du Jura. Etude phytosociologique et écologique. Beitr. Geobot. Landesaufn. Schweiz 38: 1-164.

SEITTER H. \& HANTKE R. (1988): Mögliche jüngsttertiäre Florenrelikte in der Speer-Churfïsten-Alvier-Kette und im St. Galler Oberland. Ber. St. Gall. Naturw. Ges. 83: 129-160.

SOUTHWOOD T.R.E. (1977): Habitat, the templet for ecological strategies? J. Anim. Ecol. 46: 337-365.

STEHLIK I. (2000): Nunataks and peripheral refugia for alpine plants during quarternary glaciation in the middle part of the Alps. Bot. Helv. 110: 25-30.

TAYLOR D.R., AARSSEN L.W. \& LOEHLE C. (1990): On the relationship between r/K selection and environmental carrying capacity: a new habitat templet for plant life history strategies. Oikos 58: $239-250$.

TRAVERSE A.T. (1988): Paleopalynology. Unwin Hyman, Boston.

UNGER F. (1836): Ueber den Einfluss des Bodens auf die Vertheilung der Gewaechse, nachgewiesen in der Vegetation des nordöstlichen Tirols. Rohrmann and Schweigerd, Vienna.

VON MOHL H. (1845); Über den Einfluss des Bodens auf die Verteilung der Alpenpflanzen. In: VON MOHL H. (ed.), Vermischte Schriften botanischen Inhalts. Fues, Tübingen, pp. 393-428.

WALTER H. (1960): Einführung in die Phytologie. Bd. III. Grundlagen der Pflanzenverbreitung, 1. Teil: Standortslehre. Ed. 2. Ulmer, Stuttgart.

WELTEN M. \& SUTTER R. (1982): Verbreitungsatlas der Farn- und Blütenpflanzen der Schweiz. Birkhäuser, Basel.

WiKSTRÖM N., SAVOLAINEN V. \& CHASE M.W. (2001): Evolution of the angiosperms: calibrating the family tree. Proc. Roy. Soc. London, Ser. B, Biol. Sci. 268: 2211-2220.

WOHLGEMUTH T. (1999): Diversity and distribution patterns of the Swiss flora on the Internet: the "Swiss Web Flora". Biodiv. Newslett. 15: 2.

WOHLGEMUTH T. (2002a): Alpine plant species richness in the Swiss Alps: diversity hot-spots reconsidered. Mém. Soc. Bot. Genève 3: 63-74.

WOHLGEMUTH T. (2002b): Environmental determinants of vascular plant species richness in the Swiss Alpine zone. In: KÖRNER C. \& SPEHN E. (eds.), Mountain biodiversity: a global assessment, Parthenon, New York, pp. 103-116.

Received 17 February 2003, revision received and accepted 27 June 2003 